\title{
Rehabilitation Program after Post-Traumatic Reconstruction of the Anterior Cruciate Ligament (With a Clinical Case Report)
}

\section{Ivet Koleva ${ }^{1,2 *}$ and Borislav Yoshinov ${ }^{3}$}

${ }^{1}$ Medical University of Sofia, Bulgaria

${ }^{2}$ Department of Physical and Rehabilitation Medicine, Hospital "Serdika", Sofia, Bulgaria

${ }^{3}$ Medical Faculty of Sofia University, Bulgaria

*Corresponding Author: Ivet Koleva, Professor, Medical University of Sofia, Bulgaria.

\section{Abstract}

The Anterior Cruciate Ligament (ACL) is an important stabilizer of the knee, providing almost $85 \%$ of the joint stability to forward force (especially in some aggressive twisting and jumping sports, as skiing and basketball). The common orthopedic surgical intervention is the reconstruction, performed as soon as possible after the traumatic injury.

After the orthopedic surgery, a period of rehabilitation must begin and the consultation with a medical doctor - specialist in Physical and Rehabilitation Medicine (PRM) is required.

The goal of current article is to suggest a complex PRM-algorithm of care of these patients, based on detailed literature review and on our own clinical practice.

In all traumatic knee conditions with a knee surgery, the PRM Algorithm traditionally includes functional evaluation of the knee mobility and stability and a complex PRM programme of care, including natural and preformed physical modalities. The pre-defined PRM protocol includes only physiotherapy (analytic exercises) combined with cryotherapy.

Authors consider that the traditions of some rehabilitation schools (e.g. Bulgarian) can be used. We suggest a detailed complex PRM-algorithm, including physiotherapy, cryotherapy, hydro or balneotherapy; and many preformed physical factors: functional electrical stimulations of the quadriceps femoris muscle (accentuating on the heads m.vastus lateralis and m. vastus medialis, especially on m.vastus medialis obliquus); interferential currents; Deep Oscillation; low intensity low frequency magnetic field; ultrasound or ultra-phonophoresis with non-steroidal anti-inflammatory drugs.

We propose a practical schema for a patient after ACL reconstruction, through a clinical case presentation: a male patient after reconstruction of the right ACL, after traumatic rupture of the ACL. Immediately after the orthopedic surgery, the patient was treated as inpatient in the PRM Clinic of a Bulgarian University hospital and after - as outpatient in the PRM-Department of an ambulatory Medical Center. We expose the detailed PRM-program and the obtained results in this patient.

In conclusion, we emphasize the impact of the complex PRM-programme in case of ACL-reconstruction and the efficacy for: pain relief; enhancement of the range of motion of the knee; enrichment of the functional capacity; amelioration of the neuro-muscular coordination; stabilization of the gait; improvement of the quality of life.

Keywords: Rehabilitation; Anterior Cruciate Ligament; Physical Medicine; Electrotherapy; Magnetic Field; Deep Oscillation; Laser

\section{Abbreviations}

ACL: Anterior Cruciate Ligament; DO: Deep Oscillation; FES: Functional Electrical Stimulations; IFC: Interferential Currents; LTh: LASER Therapy; MF: Magnetic Field; MMT: Manual Muscle Test; NSAIDs: Non-Steroidal Anti-Inflammatory Drugs; PRM: Physical and Rehabilitation Medicine; PT: Physiotherapy; ROM: Range of Motion; SUG: Standing Up and Go Test; TENS: Transcutaneous Electroneurostimulation; US: Ultrasound; QF: Quadriceps Femoris Muscle; 6 MWT: 6 Minutes' Walk Test

\section{Introduction}

The Anterior Cruciate Ligament (ACL) is an important stabilizer of the knee, providing almost $85 \%$ of the joint stability to forward force (especially in some aggressive twisting and jumping sports, as skiing and basketball) $[1,4]$. The function of ACL is prevention of the anterior translation of the tibia relative to femur and is a secondary limiting factor of varus angulation during knee extension $[4,7]$. The most frequent mechanism of ACL damage is a non-contact pivoting stress [7]. 
The common orthopedic surgical intervention is the reconstruction, performed as soon as possible after the traumatic injury [4]. After the orthopedic surgery, a period of rehabilitation must begin, with the support of some helping devices, as knee brace and crutches $[2,6]$. During this period, the patient usually requires consultation with a medical doctor - specialist in Physical and Rehabilitation Medicine (PRM) $[6,9,15,19]$.

The goal of current article is to suggest a complex PRM-algorithm of care of these patients, based on detailed literature review and on our own clinical practice.

\section{Summarized PRM algorithm after ACL reconstruction}

In all traumatic knee conditions with a knee surgery, the PRM Algorithm traditionally includes functional evaluation of the knee mobility and stability, and a complex PRM programme of care, including natural and preformed physical modalities. The predefined PRM protocol includes only physiotherapy (analytic exercises) combined with cryotherapy $[10,11,16,17]$.

We consider that the traditions of some rehabilitation schools (e.g. Bulgarian) can be used [8]. We apply preformed physical factors: functional electrical stimulations (FES) of the quadriceps femoris muscle $(\mathrm{QF}$ - accentuating on the heads m.vastus lateralis and $\mathrm{m}$. vastus medialis, especially on m.vastus medialis obliquus); interferential currents (IFC); Deep Oscillation (DO); low intensity low frequency magnetic field (MF); ultrasound (US) or ultra-phonophoresis with non-steroidal anti-inflammatory drugs (NSAIDs).

Physical examination and functional assessment

During the initial patient's exam, we must determine the exact post-operative day (post-op day) and we should evaluate [3,5,12]: active and passive range of motion (ROM) of the knee joint (through goniometry); muscle strength (dynamometry) and muscle weakness (Manual muscle test - MMT); joint oedema (centimetry of the knee joint); muscular hypotrophy (centimetry of the thigh - at $10 \mathrm{~cm}$ and $20 \mathrm{~cm}$ over the patella); pain (Visual analogue scale - 0-10); skin sensibility (negative sensitive patterns, as hypoesthesia; thermosensibility and vibration sensibility - through vibroesthesiometry); joint position sense (proprioception); autonomic gait (with orthosis) - trough Standing-Up and Go test (SUG-test) or 5 meters test; patient's functionality and autonomy - through the International Classification of Functioning, Disability and Health (ICF-assessment) [18-20].

\section{PRM programme Immobilization}

The knee-standardized immobilization is through application of: orthesis (with possibility of fixation and regulation of the flexion/extension), tape, elastic bandage or brace. During the first 2-3 weeks the orthesis is locked in full extension (if necessary - in 5 - 10 degrees of flexion) - except during the active exercises. During the first post-op month, the patient will receive a prescription for a lying or sitting position for a minimum 2 hours daily (afternoon) and 8 hours (at night). Immediately after the trauma and during the primary post-operative period, we prescribe the strict execution of the RICE protocol (Rest, Ice, Compression, Elevation).

\section{Preformed modalities}

From the group of preformed physical modalities we can apply [8,14]: Functional electrical stimulations - for the quadriceps muscle $(\mathrm{QF})$, especially for m.vastus medialis obliquus (VMO); Interferential currents (IFC - resulting frequency 90 - $140 \mathrm{~Hz} ; 10$ - $20 \mathrm{~min}$.) - for the knee joint; Low frequency pulsed magnetic field (MF - $16000 \mathrm{~A} / \mathrm{m}, 10$ - 20 min.) - for the knee joint; Ultra-sound (US) or ultra-phonophoresis with NSAID (0.4 - $0.8 \mathrm{~W} / \mathrm{cm}^{2}, 4$ - $8 \mathrm{~min}$.) - for the knee joint.

\section{Cryotherapy or hydrotherapy}

We recommend ice massage for 5 - 10 minutes, 3 - 5 sessions daily [14]. After the $3^{\text {rd }}$ month post-op - hydro and balneotherapy can be applied (or balneophysiotherapy - underwater exercises) [13].

\section{Kinesitherapy (Physiotherapy)}

We apply a standard kinesitherapy programme, adapted to the level of pain and functional disability [8].

We begin with passive mobilizations (under the level of pain perception) for augmentation of the active ROM of the knee joint; after that we introduce (gradually) active exercises for the range of motion and strengthening exercises (at the beginning - from a lying position; after - in sitting position, in few days - from standing position - with locked orthesis or brace). Gradually we increase the range of motion (of the orthesis and of the exercise).

We accentuate on analytic exercises for m.quadriceps femoris (QF - especially for m.vastus medialis and m.vastus lateralis) and for the hip abductors (especially for m.gluteus medius). At the beginning we use isometric exercises; gradually we include isotonic exercises, with a progressive increase of the applied resistance during exercises.

We recommend post-isometric relaxation for the m.rectus femoris, and gait training (with gradually rise of the weight bearing and progressive transition from the crutches to gait without aids).

We apply passive and mixt exercises (initiating with passive mobilizations); post isometric relaxations for the m.rectus femoris, Mobilizations of the patella (in medial - lateral and proximal-distal directions).

During the training with active exercises - the rule is from isometric to isotonic, and contra-resistance: For muscles around the knee joint (bilaterally): analytic exercises for the knee dynamic stabilizers and for knee mobility - strengthening exercises for the muscles quadriceps femoris (QF), m.triceps surae (TS); m.semitendinosus, m.semimembranosus, etc. The training of muscles of the hip joint and of the ankle joint must be done bilaterally. In some cases, we apply training of the proprioception, stretching and Theraband exercises for QF, TS and hamstring muscles. 


\begin{tabular}{|c|c|c|c|c|c|c|c|c|c|}
\hline $\begin{array}{c}\text { Period } \\
\text { (post-op } \\
\text { day/week/ } \\
\text { month) }\end{array}$ & $\begin{array}{l}\text { Localization } \\
\text {-of rehab }\end{array}$ & $\begin{array}{l}\text { Goal and } \\
\text { Tasks }\end{array}$ & $\begin{array}{l}\text { Weight } \\
\text { bearing }\end{array}$ & $\begin{array}{l}\text { Technical } \\
\text { aids } \\
\text { (brace, } \\
\text { orthosis) }\end{array}$ & $\begin{array}{l}\text { CRYO- } \\
\text { Th (Ice) }\end{array}$ & $\begin{array}{l}\text { KINESI-Th (active exercises, } \\
\text { passive mobilizations, soft } \\
\text { tissue techniques) }\end{array}$ & $\begin{array}{l}\text { Training of } \\
\text { everyday } \\
\text { activities } \\
\text { (ADL) }\end{array}$ & $\begin{array}{l}\text { Preformed } \\
\text { modalities }\end{array}$ & Notes \\
\hline $\begin{array}{l}\text { Post- } \\
\text { operative } \\
\text { Day 0-3 }\end{array}$ & $\begin{array}{c}\text { In-patient } \\
\text { OT } \\
\text { Depart-ment }\end{array}$ & $\begin{array}{c}\text { Functional } \\
\text { recovery: } \\
\text { First mo- } \\
\text { bilization } \\
\text { of the knee } \\
\text { joint - in bed; } \\
\text { Reduction } \\
\text { of pain, } \\
\text { oedema; } \\
\text { First steps }\end{array}$ & $\begin{array}{l}\text { Partial } \\
\text { weight- } \\
\text { bearing } \\
(25 \%), \\
\text { gait - } \\
\text { using } \\
\text { crutches }\end{array}$ & $\begin{array}{l}\text { Crutches (or } \\
\text { cane - in the } \\
\text { altered side); } \\
\text { Locked ortho- } \\
\text { sis or brace } \\
\text { (Flexion } 75- \\
\left.80^{\circ}\right)\end{array}$ & $\begin{array}{c}10 \text { min, } 3 \text { - } \\
7 \text { sessions } \\
\text { per day }\end{array}$ & $\begin{array}{l}\text { Range of motion exercises: } \\
\text { - } \quad \text { Flexion: heel slides; } \\
\text { Extension: Passive - using } \\
\text { towel rolls; } \\
\text { Strengthening exercises: } \\
\text { Quadriceps isometry; } \\
\text { Begin ankle strengthening } \\
\text { exercises: plantar/dorsal } \\
\text { flexion. }\end{array}$ & & $\begin{array}{l}\text { Magnetic } \\
\text { field } \\
\text { Deep Oscil- } \\
\text { lation (DO) }\end{array}$ & \multirow[t]{2}{*}{$\begin{array}{l}\text { Active exercises - to } \\
\text { patient tolerance; } \\
\text { Gradually in- } \\
\text { crease of ROM and } \\
\text { strength; } \\
\text { Observation for } \\
\text { eventual post-oper- } \\
\text { ative complications } \\
\text { (deep vein throm- } \\
\text { bosis, pulmonary } \\
\text { thromboembolism) }\end{array}$} \\
\hline $\begin{array}{l}\text { Post-op } \\
\text { Days 4-15 }\end{array}$ & $\begin{array}{l}\text { In-patient } \\
\text { PRM and Re- } \\
\text { hab Depart- } \\
\text { ment } \\
\text { of the Hospi- } \\
\text { tal }\end{array}$ & $\begin{array}{l}\text { Mobilization } \\
\text { of the knee } \\
\text { joint - in } \\
\text { sitting and } \\
\text { in standing } \\
\text { position; } \\
\text { Obtain full } \\
\text { knee exten- } \\
\text { sion }\left(0^{\circ}\right) \text { and } \\
90^{\circ} \text { of the } \\
\text { knee flexion; } \\
\text { Gait training }\end{array}$ & $\begin{array}{l}\text { Partial } \\
\text { weight- } \\
\text { bearing } \\
(50-75 \\
\text { \%), Gait } \\
\text { - with } \\
\text { crutches } \\
\text { (or cane) }\end{array}$ & $\begin{array}{l}\text { Crutches (or } \\
\text { cane); } \\
\text { Locked ortho- } \\
\text { sis or brace } \\
\left(\text { Extension } 0^{\circ} \text { ) }\right.\end{array}$ & $\begin{array}{c}15 \text { min, } 3 \times \\
\text { daily }\end{array}$ & $\begin{array}{l}\text { Range of motion exercises: } \\
\text { - } \quad \begin{array}{l}\text { Flexion: knee bends, wall } \\
\text { slides, heel slides }\end{array} \\
\text { Extension: Passive - using } \\
\text { prone hangs and towel rolls } \\
\text { Strengthening exercises: } \\
\text { - } \quad \text { Quadriceps sets with knee } \\
\text { support; } \\
\text { Hamstring digs with knee } \\
\text { support; } \\
\text { Ankle strengthening exer- } \\
\text { cises: plantar/dorsiflexion, } \\
\text { inversion/eversion } \\
\text { Verticalization } \\
\text { Balance training } \\
\text { Gait training }\end{array}$ & $\begin{array}{l}\text { Getting } \\
\text { up from a } \\
\text { seated posi- } \\
\text { tion (with } \\
\text { support on } \\
\text { crutches) }\end{array}$ & $\begin{array}{l}\text { Magnetic } \\
\text { field } \\
\text { Interfer- } \\
\text { ential cur- } \\
\text { rents (IFC) } \\
\text { Deep Oscil- } \\
\text { lation (DO) }\end{array}$ & \\
\hline $\begin{array}{l}\text { Post-op } \\
\text { Weeks 3-6 }\end{array}$ & $\begin{array}{l}\text { Out-patient } \\
\text { PRM Depart } \\
\text { of } \\
\text { the Medical } \\
\text { Center }\end{array}$ & Gait training & \begin{tabular}{|} 
Partial \\
weight- \\
bearing \\
-WB $(75$ \\
$-100 \%)$, \\
Gait - with \\
crutches \\
(or cane)
\end{tabular} & & & 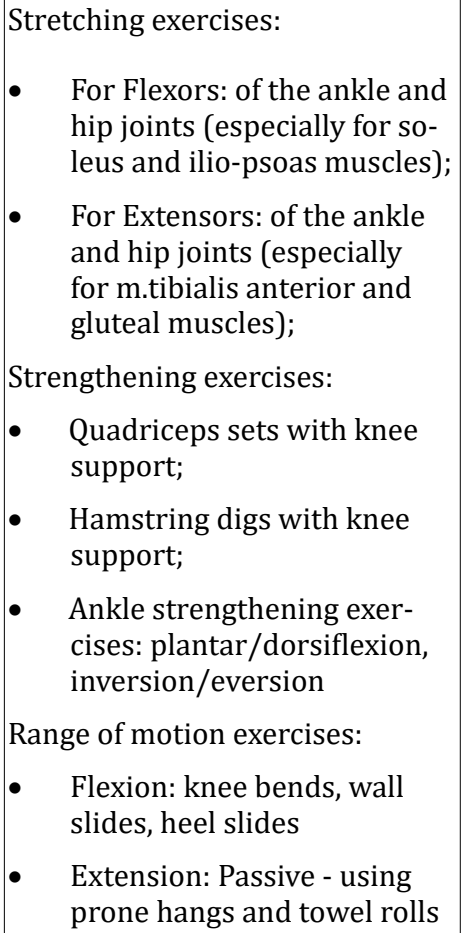 & $\begin{array}{l}\text { Walking up- } \\
\text { hill or down- } \\
\text { hill (with } \\
\text { support, but } \\
\text { gradually } \\
\text { eliminate the } \\
\text { support) }\end{array}$ & $\begin{array}{l}\text { FES for } \\
\text { m.vastus } \\
\text { medialis } \\
\text { obliquus } \\
\text { Magnetic } \\
\text { field (MF) } \\
\text { IFC } \\
\text { DO }\end{array}$ & $\begin{array}{l}\text { NB! } \\
\text { Without pressing on } \\
\text { the popliteal fossa }\end{array}$ \\
\hline
\end{tabular}




\begin{tabular}{|c|c|c|c|c|c|c|c|}
\hline $\begin{array}{l}\text { Post-op } \\
\text { Weeks 7-8 }\end{array}$ & $\begin{array}{l}\text { Out-patient } \\
\text { PRM De- } \\
\text { part of } \\
\text { the Medical } \\
\text { Center } \\
\text { or } \\
\text { AT HOME } \\
\text { Rehab }\end{array}$ & $\begin{array}{c}\text { Gait train- } \\
\text { ing } \\
\text { Goal - to } \\
\text { obtain } \\
\text { normal } \\
\text { ROM } \\
\text { and } \\
\text { Normal } \\
\text { walking }\end{array}$ & $\begin{array}{l}\text { TWB } \\
\text { Gait - } \\
\text { with } \\
\text { cane or } \\
\text { without } \\
\text { technical } \\
\text { aids }\end{array}$ & $\begin{array}{l}\text { Manual therapy: } \\
\text { Mobilizations of the patella (in } \\
\text { proximal, distal; lateral and } \\
\text { medial directions) } \\
\text { Stretching exercises: } \\
\text { For Flexors: of the ankle and hip } \\
\text { joints (especially for soleus and } \\
\text { ilio-psoas muscles); } \\
\text { For Extensors: of the ankle } \\
\text { and hip joints (especially for } \\
\text { m.tibialis anterior and gluteal } \\
\text { muscles); } \\
\text { Strengthening exercises: } \\
\text { - Quadriceps sets with knee } \\
\quad \text { support; } \\
\text { - Hamstring digs with knee } \\
\text { support; } \\
\text { - Ankle strengthening exer- } \\
\quad \text { cises: plantar/dorsiflexion, } \\
\text { inversion/eversion }\end{array}$ & $\begin{array}{l}\text { Getting } \\
\text { up from } \\
\text { a seated } \\
\text { position } \\
\text { (without } \\
\text { support); } \\
\text { Going up or } \\
\text { down stairs }\end{array}$ & $\begin{array}{l}\text { FES for } \\
\text { m.vastus } \\
\text { medialis } \\
\text { obliquus } \\
\text { or Ultra- } \\
\text { sound of } \\
\text { the knee } \\
\text { or MF or } \\
\text { IFC }\end{array}$ & \\
\hline $\begin{array}{l}\text { Post-op } \\
\text { Months } \\
2-4\end{array}$ & $\begin{array}{l}\text { Out-patient } \\
\text { PRM De- } \\
\text { part of } \\
\text { the Medical } \\
\text { Center } \\
\text { or } \\
\text { AT HOME } \\
\text { Rehab }\end{array}$ & $\begin{array}{l}\text { Participa- } \\
\text { tion in all } \\
\text { ADL } \\
\\
\text { Training } \\
\text { of working } \\
\text { activities }\end{array}$ & & $\begin{array}{l}\text { MANUAL therapy: } \\
\text { - } \quad \text { Tibio-femoral distraction, } \\
\text { - } \quad \text { Anterior tibial glide, } \\
\text { - } \quad \text { Posterior glide; } \\
\text { and Mulligan } \\
\text { Stretching exercises: } \\
\text { - } \quad \text { For Flexors: of the ankle } \\
\quad \text { and hip joints (especially } \\
\quad \text { for soleus and ilio-psoas } \\
\text { muscles); } \\
\text { - For Extensors: of the ankle } \\
\quad \text { and hip joints (especially } \\
\quad \text { for m.tibialis anterior and } \\
\text { gluteal muscles); } \\
\text { Strengthening exercises: } \\
\text { - } \quad \text { Quadriceps sets with knee } \\
\quad \text { support; } \\
\text { - Hamstring digs with knee } \\
\quad \text { support; } \\
\text { Ankle strengthening exercises: } \\
\text { plantar/dorsiflexion, inversion/ } \\
\text { eversion } \\
\text { ERGO-Therapy }\end{array}$ & $\begin{array}{c}\text { Kneeling, } \\
\text { squatting } \\
\text { Some } \\
\text { sports } \\
\text { training - } \\
\text { swimming, } \\
\text { sitting } \\
\text { bicycle; } \\
\text { Training } \\
\text { of working } \\
\text { activities }\end{array}$ & $\begin{array}{c}\text { FES for } \\
\text { m.vastus } \\
\text { medialis } \\
\text { obliquus } \\
\text { or MF }\end{array}$ & PRM Control \\
\hline $\begin{array}{l}\text { Post-op } \\
\text { Months } \\
5-6\end{array}$ & $\begin{array}{l}\text { AT HOME } \\
\text { Rehab }\end{array}$ & Every day & & $\begin{array}{l}\text { Stretching exercises } \\
\text { Exercising Muscles that Sur- } \\
\text { round the Knee } \\
\text { Working the Hip Stabilizers } \\
\text { Increasing Muscle Endurance } \\
\text { Cardio-respiratory fitness - } \\
\text { including stationary bicycle, } \\
\text { swimming, etc. }\end{array}$ & & & OT control \\
\hline $\begin{array}{l}\text { Longlife } \\
\text { mainte- } \\
\text { nance } \\
\text { rehabili- } \\
\text { tation pro- } \\
\text { gramme }\end{array}$ & $\begin{array}{l}\text { AT HOME } \\
\text { Rehab }\end{array}$ & $\begin{array}{c}3 \text { seances } \\
\text { weekly }\end{array}$ & & $\begin{array}{l}\text { Stretching exercises } \\
\text { Exercising Muscles that Sur- } \\
\text { round the Knee } \\
\text { Working the Hip Stabilizers } \\
\text { Increasing Muscle Endurance } \\
\text { Cardio-respiratory fitness - } \\
\text { including stationary bicycle, } \\
\text { swimming, etc. }\end{array}$ & $\begin{array}{c}\text { Sports } \\
\text { Working } \\
\text { activities } \\
\text { Leisure } \\
\text { activities }\end{array}$ & $\begin{array}{c}\text { Peri- } \\
\text { odically } \\
\text { (monthly } \\
\text { or every } 2 \\
\text { months): } \\
10-15 \text { se- } \\
\text { ances DO } \\
\text { or MF or } \\
\text { IFC }\end{array}$ & \\
\hline \multicolumn{4}{|c|}{ Control by MD, specialists in PRM and OT } & & & & \\
\hline
\end{tabular}

\section{Table 1}




\section{Ergotherapy (Occupational therapy)}

We introduce gradually different everyday activities, including sports: stationary bicycle, swimming, etc.

\section{Gait training}

The gait training must be effectuated with progressive weight bearing - from non-weight bearing during the first 2 - 4 weeks, $50 \%$ to full weight bearing and normalization of the gait at the $6^{\text {th }}$ month (at the beginning - with crutches, after that - with cane, finally - without technical aids).

\section{Clinical PRM algorithm after ACL reconstruction}

\section{Management of the patient after ACL reconstruction}

The clinical PRM-algorithm after ACL reconstruction is presented on the table 1 .

\section{Prevention of complications}

In every period of the rehabilitation process, the patient is strictly observed for possible complications: deep vein thrombosis, pulmonary thromboembolism, muscle or joint contracture, etc.

\section{Prognosis}

The ACL reconstruction is a highly successful operation. 90$95 \%$ of patients can be expected to return to full sports participation with 6 months and with aggressive (but well dosed) rehabilitation.

Practical schema for a patient after ACL reconstruction (clinical case presentation)

We will present a case of a male patient with operation of the right ACL (alloplastic reconstruction), after traumatic rupture of the ACL. Immediately after the orthopedic surgery, the patient was treated as inpatient in the PRM Clinic of a Bulgarian University hospital and after - as outpatient in the PRM-Department of an ambulatory Medical Center.

\section{Personal data (History of the disease)}

\section{Patient's complaints}

The patient suffer from moderate pain in the right knee and stiffness of muscles around it. He has difficulties in long time mobility, decrease in autonomy in activities of daily living (ADL). Movements of the right knee are painful, likewise the gait. Patient's complaints increase at the end of the day and after physical activity.

\section{Anamnesis}

This is a post interventional procedure (ACL alloplasty) rehabilitation status. The traumatic injury of the right knee was consequence of a fall during bicycling. The patient realized most of 5 PRM-courses (of 5 days each) and actually he has the full ROM of the knee joint.

\section{Comorbidities}

Cystic formation in the fossa poplitea of the left knee (the healthy knee); Lumbar ostheochondrosis.

Clinical data

From the clinical assessment of the patient: Age-correspondent with the real. Thorax: Pulmo-vesicular respiration, without crepitations. Cor-rhythmic cardiac activity with normal frequency, RR 120/60 mm Hg, Pulsus = 62 beats per minute. Abdomen: soft, no painful. Hepar and lien - non-palpable.

From the Neurological exam: Vertebral syndrome with paravertebral muscle spasm, limitations of the lumbar spine ROM. Radicular syndrome L5 bilaterally ( $>$ D), with hypoesthesia L5 and knee hyporeflexia.

From the Orthopedical exam: Upper limbs and left leg: ROM of joints and muscle strength with normal values. Limited range of motion of the right knee joint. Post-operative cicatrix - without complications.

\section{Exams (Lab and Imagery)}

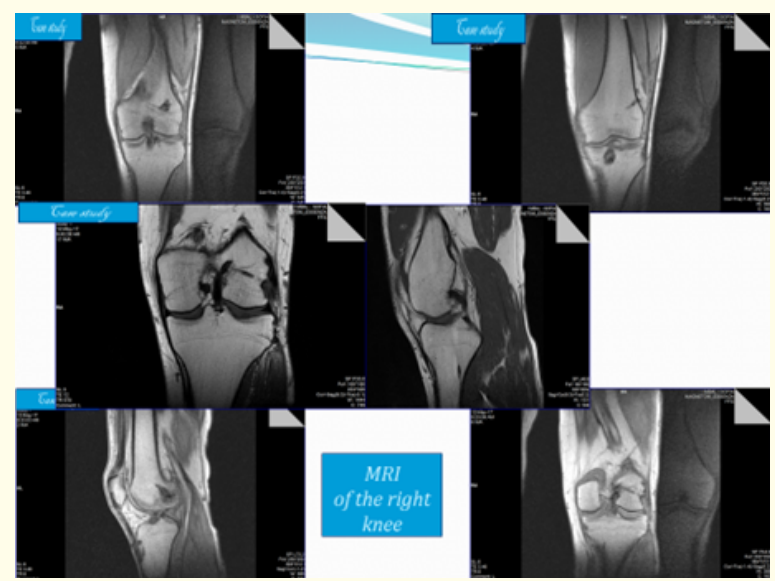

Figure 1: Magnetic resonance imagery of the right knee.

Functional assessment

We applied detailed kinesiological analysis. The results of the goniometry of the right knee joint was S 0-0-165. The patient has a developed vertebral syndrome with paravertebral muscle spasm, limitations of the range of motion of the lumbar spine. He has a good rehabilitation potential.

Results of the ICF assessment: Our patient has impairments of body functions (knee pain, muscle weakness, and restricted knee ROM) and changes in body structures; activity limitations (limited walking \& staying ability and endurance); participation restrictions (reduced participation in leisure activities, especially sports); decrease of the patient's quality of life. 
The evaluation of the physical performance was realized by the 6 Minutes Walk Test (6 MWT) - $450 \mathrm{~m}$ - with pain - before rehabilitation; after 1 week - 550 meters.

\section{Complete diagnosis}

Before the operation: Ruptura ligamentum cruciatum anterius dex. (ACL rupture).

After the operation: Status post reconstructionem ligamentum cruciatum anterior (pro LCA rupturam) (ACL-alloplastic reconstruction).

Comorbidities: Ostheochondrosis lumbalis. Radiculopathia L5 bilateralis (S > D).

\section{PRM programme}

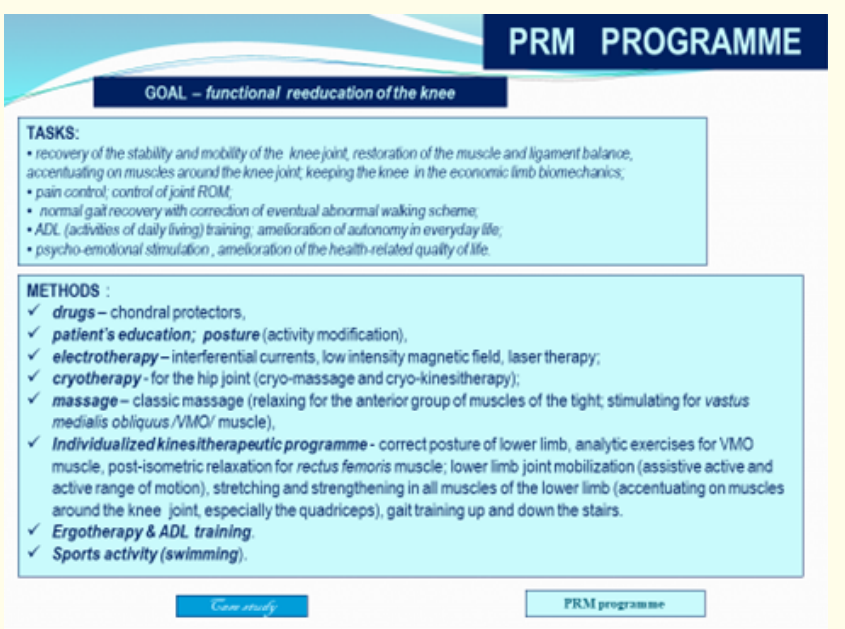

Figure 2: The PRM programme.

\section{Results of the applied PRM course}

The functional assessment at the end of the PRM-course demonstrated an increase of the joint ROM (goniometry of the right knee: S 0-0-180). The pain was significantly reduced (from VAS 7 to VAS 1 ). The results of the 6 minutes' walk test was $610 \mathrm{~m}$ (at the end of the PRM course).

\section{Conclusion}

In conclusion, we must emphasize the impact of the complex PRM-programme in case of ACL-reconstruction and the efficacy for pain relief; enhancement of the range of motion of the knee; enrichment of the functional capacity; amelioration of the neuromuscular coordination; stabilization of the gait; improvement of the quality of life.

\section{Recommendations}

After the dehospitalization the patient must continue with the PT-programme (auto-training - at home). The recommended sport's activity is swimming. The next control and respective PRM-course must be effectuated in 3 months.

\section{Acknowledgements}

Part of the Physiotherapeutic program is elaborated by the first author under the ERASMUS Plus programme - project "Collaborative learning for enhancing practical skills for patient-focused interventions in gait rehabilitation after orthopedic surgery (CORskills)", No 2015-1-Ro01-KA202-015230.

\section{Conflict of Interest}

No conflict of interest.

\section{Bibliography}

1. Shankman G. "Fundamental Orthopedic Management for the Physical Therapist Assistant". St. Louis: Mosby Year Book (1997).

2. American Academy of Physical Medicine and Rehabilitation Task Force on Medical Inpatient Rehabilitation Criteria (JL Melvin Chair). Standards for Assessing Medical Appropriateness Criteria for Admitting Patients to Rehabilitation Hospitals or Units (2006).

3. Bethoux F and Calmels P. "Guide de mesure et d'évaluation en médecine physique et de réadaptation”. Paris: Roche (2003).

4. Cyriax J and Russell G. "Textbook of orthopedic Medicine". London: Chirchill-Livingstone (1981).

5. Daniels L and Worthingham C. "Evaluation de la fonction musculaire". Le TESTING - techniques de l'examen manuel. Paris: Maloine (1973): 88-90.

6. DeLisa JA. "Physical Medicine and Rehabilitation - principles and practice". $4^{\text {th }}$ Edition. Philadelphia: Lippincott, Williams and Wilkins (2005).

7. Floyd RT. "Manual of structural kinesiology". $16^{\text {th }}$ edition. New York: Mc Graw-Hill (2007).

8. Grasp and gait rehabilitation (bases). Monograph. (In English). Edited by prof. Ivet Koleva, and prof. Elena Avramescu. Authors: I Koleva, RD Yoshinov, M Zheleva, Y Zhelev, B Yoshinov, RR Yoshinov; ET Avramescu, D Kamal, C Kamal, MR Trăistaru. - Sofia: 'SIMEL PRESS (2017): 396.

9. Haig AJ. "Practice of physical medicine and rehabilitation on both sides of the Atlantic: differences and the factors that drive them". European Journal of Physical and Rehabilitation Medicine 44.2 (2008): 111-115.

10. Knee Arthroscopy Physical Therapy Protocol (2016).

11. Koleva I., et al. "Rehabilitation guidelines of operational standard procedures in rehabilitation after lower limb orthopedic surgery". In: Education and New Developments, Edited by Mafalda Carmo, Lisbon (2017): 594-598. 
12. Koleva I., et al. "Functional assessment in orthopedical and traumatological rehabilitation: impact of International Classification of Functioning". Evolutio-Medicine 2 (2016): 22-29.

13. Koleva I., et al. "Efficacy of hydro-, balneo- and peloidotherapy in the pain management and quality of life of patients with socially-important diseases and conditions of the locomotory and nervous system: Bulgarian experience". Balnea 10 (2015).

14. Koleva I., et al. "Physical Analgesia. Edited by prof. Ivet Koleva. - Saint-Denis (France): Connaissances et Savoirs". Sciences Sante (2018):146.

15. Melvin JL. "Physical and rehabilitation medicine: comments related to the White book on physical and rehabilitation medicine in Europe". European Journal of Physical and Rehabilitation Medicine 44.2 (2008): 117-119.

16. Physical Therapy Protocols (2016).

17. Physical Therapy Post-operative Rehabilitation Protocols (2016).

18. Stucki G., et al. "Value and application of the ICF in rehabilitation medicine". Disability and Rehabilitation 24 (2002): 932938.

19. White Book on Physical and Rehabilitation Medicine in Europe. Produced by the Section of Physical and Rehabilitation Medicine, Union Europeenne des Medecins Specialistes (UEMS), the European Board of Physical and Rehabilitation Medicine and l'Academie Europeenne de Medicine de Readaptation in conjunction with the European Society of Physical and Rehabilitation Medicine (ESPRM). C Gutenbrunner, AB Ward, MA Chamberlain Editors. Journal of Rehabilitation Medicine 1.45 (2007): 1-48.

20. World Health organization. "International Classification of Functioning, Disability and Health (ICF)". Geneva, WHO (2001).

\section{Assets from publication with us}

- Prompt Acknowledgement after receiving the article

- Thorough Double blinded peer review

- Rapid Publication

- Issue of Publication Certificate

- High visibility of your Published work

Website: https://www.actascientific.com/

Submit Article: https://www.actascientific.com/submission.php Email us: editor@actascientific.com

Contact us: +919182824667 